УДК 338.48

\title{
МЕТОДИЧНІ ПІДХОДИ ОЦІНКИ КОНКУРЕНТОСПРОМОЖНОСТІ ПІДПРИЕМСТВ ГОТЕЛЬНОГО БІЗНЕСУ
}

\section{METHODICAL APPROACHES TO ASSESSING THE COMPETITIVENESS OF HOTEL BUSINESS ENTERPRISES}

\author{
Савко Оксана Ярославівна \\ кандидат економічних наук, доцент, \\ Івано-Франківський національний технічний університет нафрти і газу \\ ORCID: https://orcid.org/0000-0002-7282-7731 \\ Загайкевич Ольга юріївна \\ студентка, \\ Івано-Франківський національний технічний університет насрти і газу \\ ORCID: https://orcid.org/0000-0001-7036-1424 \\ Savko Oksana, Zahaikevych Olha \\ Ivano-Frankivsk National Technical University of Oil and Gas
}

\begin{abstract}
Стаття присвячена методичних підходам до оцінки конкурентоспроможності підприємства. Зауважено, що для оцінки конкурентоспроможності готельних підприємств важливо враховувати особливості нематеріального характеру їхньої діяльності. Як один з найпоширеніших інструментів стратегічного управління та найважливіших етапів аналізу діяльності суб'єкта господарювання і проведення оцінки конкурентоспроможності в роботі здійснено SWOT-аналіз діяльності підприємства, яке належить до сорери готельного бізнесу. Він дозволив структурувати основні можливості та загрози, сильні і слабкі сторони його діяльності. На основі бальної оцінки відзначено, що у досліджуваного підприємства переважають сильні сторони, а також значний вплив мать загрози, враховуючи вплив пандемії коронавірусу та його наслідки.
\end{abstract}

Ключові слова: конкурентоспроможність підприємства, готельний бізнес, методичні підходи, SWOTаналіз, ефективність.

Статья посвящена методическим подходам к оценке конкурентоспособности предприятия. Примечательно, что для оценки конкурентоспособности гостиничных предприятий важно учитывать особенности нематериального характера их деятельности. В качестве одного из наиболее распространенных инструментов стратегического управления и важнейших этапов анализа деятельности предприятия, и проведения оценки конкурентоспособности в работе осуществлен SWOT-анализ деятельности предприятия, относящегося к сорере гостиничного бизнеса. Он позволил структурировать главные возможности и угрозы, сильные и слабые стороны его деятельности. На основе балльной оценки отмечено, что у исследуемого предприятия преобладают сильные стороны, а также значительное влияние имеют угрозы, учитывая влияние пандемии коронавируса и его последствия.

Ключевые слова: конкурентоспособность предприятия, гостиничный бизнес, методические подходы, SWOT-анализ, эфффективность.

The article is devoted to methodological approaches to assessing the competitiveness of an enterprise, since such an assessment is necessary to justify current and strategic decisions in the company's activities. Assessment of the competitiveness of enterprises is the basis for the formation of further scenarios, plans, development strategies and obtaining new competitive advantages in the market. It is noted that there is no single methodology for assessing competitiveness that would be used, since the interpretation of the very concept of competitiveness is ambiguous, and there are different levels of competitiveness and industries that require diagnostics. It is noted that each of the methods for assessing competitiveness uses a special set of factors and analyzed variables, to take into account the sectoral characteristics of the activities of economic entities in various methods, researchers are allowed to choose the number of variables to be analyzed; when combining several methods, conflicting results 
can be obtained, and this should be taken into account by the researcher. It is noteworthy that when assessing the competitiveness of hotel enterprises, it is important to take into account the features of the intangible nature of their activities. Hotel enterprises belong to the service sector, because the result of their activities is temporary accommodation services with mandatory maintenance. Research shows that one of the common strategic management tools used at the initial stages to assess the competitiveness of an enterprise is a SWOT analysis. Its use allows you to systematize the available information about the strengths and weaknesses of the organization, as well as its opportunities and threats, which allows you to further conduct a thorough and comprehensive analysis of the competitiveness of the enterprise. The work carried out SWOT - an analysis of the activities of an enterprise related to the hotel business. It allowed structuring the main opportunities and threats, strengths and weaknesses of its activities. Based on the scoring, it was noted that the strengths of the enterprise under study prevail, and threats have a significant impact, given the impact of the COVID-19 pandemic and its consequences.

Keywords: enterprise competitiveness, hotel business, methodological approaches, SWOT analysis, efficiency.

Постановка проблеми. Розвиток ринкових відносин та поглиблення конкурентної боротьби створюють нові вимоги до діяльності підприємств сорери гостинності. Підприємства готельного бізнесу $€$ вагомою складовою сфери послуг та тісно пов'язані 3 розвитком туризму у регіонах країни, оскільки забезпечують споживачів послугами з проживання та відпочинку. Тому оцінка конкурентоспроможності таких підприємств є основою та підґрунтям для фрормування подальших сценаріїв, планів, стратегій розвитку та отримання нових конкурентних переваг на ринку.

Аналіз останніх досліджень та публікацій. Методичним підходам до оцінки конкурентоспроможності підприємств відображені у працях таких науковців, як: Драган O.І., Городня Т.А., Дробитько Н.А., Іванов Ю.Б., Костюк Л.А., Левицька А. О., Рибницький Д.О., Сахно І.В., Сомова О.Є., Тищенко Ю.Б. та інших, які зробили ґрунтовний внесок у розвиток питань конкурентоспроможності підприємства, теоретичних та методичних підходів, методів до її оцінки.

Виділення невирішених раніше частин загальної проблеми. Проте потребують подальшого дослідження практичне застосування наявних методичних підходів до оцінки конкурентоспроможності, а також використання інструментів стратегічного управління для аналізу діяльності підприємств готельного бізнесу та виділення напрямів подальшого їх розвитку особливо в період пандемії.

Постановка завдання. Метою статті $\epsilon$ виокремлення методичних підходів до оцінки конкурентоспроможності та проведення SWOT-аналізу діяльності підприємства сфери гостинності, як одного з поширених та дієвих інструментів при аналізі інфрормації про об'єкт дослідження та, при початковому етапі проведення оцінки конкурентоспроможності.

Виклад основного матеріалу дослідження. Конкурентоспроможність підприємства розглядається як здатність утримували лідируючі позиції на ринку, залучати нових клієнтів та забезпечувати лояльність існуючих, фрункціонувати прибутково, отримати позитивний імідж серед споживачів та стейкхолдерів. Це вимагає від власників бізнесу та топ-менеджменту компаній бути в «тренді» та враховувати реалії сьогодення особливо у період пандемії. Тому важливим елементом оцінки конкурентоспроможності $€$ виокремлення та використання методичних підходів, які зможуть допомогти в аналізі відповідної інорормації для подальшого прийняття управлінських рішень.

Методи оцінки конкурентоспроможності використовуються для обґрунтування різних поточних та стратегічних рішень, зокрема:

- комплексного вивчення ринку і вибору напрямів діяльності підприємства;

- розробки заходів щодо підвищення конкурентоспроможності;

- оцінювання перспектив продажу конкретних виробів (послуг) і фрормуванні структури продажів (надання послуг) тощо [1, с. 39].

Варто відмітити, що немає єдиної методики, яка б використовувалася для оцінки конкурентоспроможності підприємства, оскільки трактування самого поняття конкурентоспроможності $€$ неоднозначним, а також існують різні рівні конкурентоспроможності та галузі, що потребують діагностики.

У зв'язку із вищезазначеним науковці проводять класифрікацію методів оцінок конкурентоспроможності підприємства, виділяючи їх певні групи.

Так, Л.А. Костюк [2] пропонує поділяти методи оцінки конкурентоспроможності підприємства на 5 груп: методи оцінки конкурентоспроможності підприємства за ринковою часткою, матричні методи, методи, засновані на теорії есрективної конкуренції, методи, засновані на теорії якості товару та інтегральні методи.

Інші автори [3, с. 87] пропонують виокремлювати наступні групи методів, а саме: засно- 
вані на аналізі порівняльних переваг; ті що базуються на теорії рівноваги фрірми і галузі; побудовані на основі теорії ефективної конкуренції; засновані на теорії якості товару; побудовані на основі матриць; інтегральні; засновані на теорії мультиплікатора; засновані на визначенні позиції в конкуренції з точки зору стратегічного потенціалу підприємства; засновані на порівнянні з еталоном.

На основі аналізу літературних джерел B.І. Сахно [4] виділяє такі групи методів оцінки конкурентоспроможності підприємства: методи, засновані на теорії конкурентних переваг та теорії ефективної конкуренції; методи, в основі яких лежить теорія якості товару; матричні методи; інтегральний метод.

3 метою типізації та узагальнення методичних підходів О.Є. Сомова [5] у своєму дослідженні пропонує виокремлювати п'ять основних груп методів оцінки конкурентоспроможності: методи, що базуються на описі конкурентної боротьби; методи, засновані на узагальненні думок експертів; методи оцінки конкурентоспроможності товару та конкурентоспроможності підприємства; методи, засновані на розрахунку інтегрального коефріцієнта за фрінансовими і техніко-економічними показниками; методи оцінки конкурентоспроможності підприємства на основі аналізу рентабельності, грошових потоків і вартості бізнесу.

У роботі [1, с. 47] автор зазначає методи оцінки конкурентоспроможності, які поширені у світі, а саме: метод, що заснований на теорії ефрективної конкуренції; підходи до оцінки конкурентоспроможності підприємства, які пов'язують її рівень з показниками якості (конкурентоспроможності) продукції, що випускається; методи, засновані на теорії конкурентної переваги; метод бенчмаркінгу; методи, що засновані на методиках комплексної оцінки срінансово-господарської діяльності підприємства та ін.

Слід відмітити, що кількісні методи дають змогу оцінювати реальні шанси суб'єкта господарювання у конкурентній боротьбі за привабливі стратегічні зони господарювання та приймати виважені, з тактичного та стратегічного погляду, управлінські рішення [6, с. 227]. Якісні методи оцінювання здебільшого мають низький ступінь математичної фрормалізації, їм властива трудомісткість реалізації та дискретність оцінки. Вони не дають можливості використовувати оцінку конкурентоспроможності підприємства в процесі аналізу та визначення пріоритетних напрямів посилення конкурентних позицій на ринку [7, с. 155].
Спеціальні методи оцінки - це методи, що дозволяють оцінити конкурентоспроможність підприємства за окремими напрямами його діяльності - виробничим, маркетинговим, інноваційними, фрінансовим тощо. Комплексні методи базуються на комплексному підході щодо оцінки конкурентоспроможності підприємства [8].

Таким чином, кожен із наведених методів оцінки конкурентоспроможності підприємства має свої переваги та недоліки та може бути використаний в залежності від умов фрункціонування того чи іншого підприємства та специсріки його діяльності.

Це підтверджується дослідженнями та висновками Драган О.І. [1, с. 65], яка зазначає, що кожний із методів оцінки конкурентоспроможності застосовує спеціальний набір оракторів та аналізованих змінних; для урахування галузевих особливостей діяльності суб'єктів господарювання в різних методиках дозволяється обирати дослідникам кількість змінних, що підлягають аналізу; при поєднанні декількох методів можна отримати суперечливі результати, і на це треба зважати дослідникові.

Необхідно зауважити, що при проведенні оцінки конкурентоспроможності готельних підприємств важливо враховувати особливості нематеріального характеру їхньої діяльності. Готельні підприємства належать до сорери послуг, адже результатом їхньої діяльності $€$ послуги 3 тимчасового проживання 3 обов'язковим обслуговуванням.

Підприємства готельного бізнесу займають чільне місце у соціальні ссрері країни і сприяють задоволенню першочергових потреб подорожуючих у проживанні та відпочинку.

Дослідження показують, що одним із поширених методів, який використовують на початкових етапах для оцінки конкурентоспроможності підприємства є SWOT-аналіз. Його використання дозволяє систематизувати наявну інформацію щодо сильних і слабких сторін організації, а також її можливостей і загроз, що дає змогу в подальшому провести ґрунтовний та всебічний аналіз конкурентоспроможності суб'єкта господарювання.

Нами проведено оцінку конкурентоспроможності товариства 3 обмеженою відповідальністю «Хотел Менеджмент Груп», до складу якого входить готельно-оздоровчий комплекс преміум-класу «Mirotel Resort \& Spa», вілла «Христина» та готель «VESNA», що знаходяться в серці міста-курорту Трускавця [9]. 


\section{SWOT-аналіз діяльності ТOB «Хотел Менеджмент Груп»}

\begin{tabular}{|c|c|}
\hline Сильні сторони (S) & Слабкі сторони (W) \\
\hline $\begin{array}{l}\text { - наявність у підприємства готелів різної } \\
\text { цінової категорії (8); } \\
\text { - вигідне розміщення у місті-курорті } \\
\text { Трускавець (7); } \\
\text { - високий рівень кваліфікікації працівників (8); } \\
\text { - високий імідж компанії на ринку готельних } \\
\text { послуг (8); } \\
\text { - широкий асортимент послуг (7); } \\
\text { - наявність лікувально-діагностичного центру } \\
\text { (8); } \\
\text { - використання новітніх технологій (7) }\end{array}$ & $\begin{array}{l}\text { - недостатнє стимулювання збуту послуг } \\
\text { готелів (5); } \\
\text { - відсутність програми лояльності клієнтів (4); } \\
\text { - вартість окремих послуг перевищує } \\
\text { вартість послуг конкурентів (3); } \\
\text { - відсутність окремих послуг у готелях «Весна» } \\
\text { та «Христина» і необхідність відвідування } \\
\text { комплексу «Міrotel Resort \& Sра» (5); } \\
\text { - сезонне завантаження готельних номерів (5) }\end{array}$ \\
\hline Сума балів: 53 & Сума балів: 22 \\
\hline Можливості (O) & \\
\hline $\begin{array}{l}\text { - розширення асортименту послуг (7); } \\
\text { - зростання частки ринку (5); } \\
\text { - залучення інвестицій та розширення } \\
\text { діяльності (4); } \\
\text { - залучення нових груп споживачів (6); } \\
\text { - покращення якості послуг (8); } \\
\text { - досягнення лідируючих позицій на ринку (6); } \\
\text { - можливість інтеграції з іншими оздоровчими } \\
\text { комплексами (4). }\end{array}$ & $\begin{array}{l}\text { - поява нових конкурентів (4); } \\
\text { - зростання цін постачальників (5); } \\
\text { - введення в дію нових законодавчих актів, } \\
\text { що погіршують умови діяльності (5); } \\
\text { - економічна криза (6); } \\
\text { - високі темпи інфрляції (5); } \\
\text { - подальше поширення коронавірусу (8); } \\
\text { - зміна уподобань та потреб користувачів } \\
\text { готельних послуг (4); } \\
\text { - закриття кордонів (6); } \\
\text { - вичерпання, забруднення джерел } \\
\text { мінеральних вод (5) }\end{array}$ \\
\hline Сума балів: 40 & Сума балів: 48 \\
\hline
\end{tabular}

На основі наявної інфрормації про ринкову позицію ТОВ «Хотел Менеджент Груп», опитувань провідних орахівців товариства, наукових публікацій з даної тематики, експертів та за допомогою бальної оцінки проведено SWOTаналіз (табл. 1).

Проведений SWOT-аналіз діяльності Товариства $з$ обмеженою відповідальністю «Хотел Менеджмент Груп» показав, що підприємство має значну кількість фракторів, що підкреслюють його сильні сторони, проте і не позбавлене недоліків. Окрім того підприємство має чимало можливостей для подальшого розвитку, проте потребує врахування існуючих загроз, серед яких сьогодні на перший план виходить поширення коронавірусу, що значно зменшило потік туристів у попередній період.

Отже, за результатами SWOT-аналізу ТОВ «Хотел Менеджмент Груп» більша оцінка сильних сторін становить 53 та переважає над слабкими сторонами, а також загрози мають більший вплив зі сторони зовнішнього середовища в умовах пандемії, ніж можливості.

Висновки. Оцінки конкурентоспроможності підприємства ґрунтується на відповідних методичних підходах. Кожен 3 яких має свої переваги та недоліки. Вибір того чи іншого методу залежить від специсріки діяльності досліджуваного підприємства та мети проведеного дослідження.

SWOT-аналіз є дієвий інструментом стратегічного управління, який використовують при прийнятті рішень щодо подальшої діяльності суб'єкта господарювання, також він $€$ початковим етапом при проведенні оцінки діяльності підприємства та його конкурентоспроможності.

Подальшим дослідженням повинна стати проведення розрахунку інтегрального показника оцінки конкурентоспроможності підприємств готельного бізнесу.

\section{СПИСОК ВИКОРИСТАНИХ ДЖЕРЕЛ:}

1. Драган О.І. Управління конкурентоспроможністю підприємств: теоретичні аспекти : монограсрія. Київ : ДАКККіМ, 2006. $160 \mathrm{c}$.

2. Костюк Л.А. Теоретичні та методичні засади оцінки конкурентоспроможності. Збірник наукових праць Таврійського державного агротехнологічного університету. 2012. Випуск 2. С. 22-30. 
3. Иванов Ю.Б., Тищенко Ю.Б., Дробитько Н.А. Конкурентоспособность предприятия: оценка, диагностика, стратегия : монография. Харьков : ХГЭУ, 2003. 349 с.

4. Сахно І.В. Аналіз основних методичних підходів до оцінки конкурентоспроможності підприємств. Збірник наукових праць Таврійського державного агротехнологічного університету (економічні науки). 2012. № 2. Ч. 2. С. 385-390.

5. Сомова О.Є. Вартісна оцінка рівня конкурентоспроможності підприємств машинобудування : авторефр. дис. на здобуття наук. ступеня канд. екон. наук : 08.00.04 «Економіка та управління підприємствами». ПВНЗ Європейський ун-т. Київ, 2008. 19 с.

6. Рибницький Д.О., Городня Т.А. Сучасні підходи до оцінювання конкурентоспроможності підприємства. Науковий вісник НЛтУ України. 2010. Випуск 20.9. С. 227-230.

7. Левицька А.О. Методи оцінки конкурентоспроможності підприємства: вітчизняні та закордонні підходи до класифрікації. Механізм регулювання економіки. 2013. № 4. С. 155-163.

8. Яцура В.В., Замроз М.В. Аналіз методів оцінки конкурентоспроможності підприємств. Вісник Волинського інституту економіки та менеджменту. Збірник наукових пращь. 2011. № 2. URL: http://archive.nbuv.gov.ua/ portal/Soc_Gum/Vviem/2011_2/18.pdf

9. ТОВ «Хотел Менеджмент Груп». URL: https://hotel-management-group.business-guide.com.ua/ (дата звернення: 07.12.2021).

\section{REFERENCES:}

1. Drahan O.I. (2006) Upravlinnia konkurentospromozhnistiu pidpryiemstv: teoretychni aspekty [Management of enterprise competitiveness: theoretical aspects]: monohrafiya [a monograph]. Kyiv: DAKKKiM, 160 p. (in Ukrainian)

2. Kostiuk L.A. (2012) Teoretychni ta metodychni zasady otsinky konkurentospromozhnosti [Theoretical and methodological principles of competitiveness assessment]. Zbirnyk naukovykh prats Tavriiskoho derzhavnoho ahrotekhnolohichnoho universytetu, no. 2, pp. 22-30. (in Ukrainian)

3. Ivanov Yu.B., Tischenko Yu.B., Drobitko N.A. (2003) Konkurentosposobnost predpriyatiya: otsenka, diagnostika, strategiya [Competitiveness of an enterprise: assessment, diagnostics, strategy]: monografiya [a monograph]. Kharkiv: HGEU, 349 p. (in Russian)

4. Sakhno I.V. (2012) Analiz osnovnykh metodychnykh pidkhodiv do otsinky konkurentospromozhnosti pidpryiemstv [Analysis of the main methodological approaches to assessing the competitiveness of enterprises]. Zbirnyk naukovykh prats Tavriiskoho derzhavnoho ahrotekhnolohichnoho universytetu (ekonomichni nauky), no. 2(2), pp. 385-390. (in Ukrainian)

5. Somova O.Ye. (2008) Vartisna otsinka rivnia konkurentospromozhnosti pidpryiemstv mashynobuduvannia [Cost assessment of the level of competitiveness of machine-building enterprises]: avtoref. dys. na zdobuttia nauk. stupenia kand. ekon. nauk: 08.00.04 «Ekonomika ta upravlinnia pidpryiemstvamy» (PhD Thesis). PVNZ Yevropeiskyi un-t. Kyiv, 19 p. (in Ukrainian)

6. Rybnytskyi D.O., Horodnia T.A. (2010) Suchasni pidkhody do otsiniuvannia konkurentospromozhnosti pidpryiemstva [Modern approaches to assessing the competitiveness of the enterprise]. Naukovyi visnyk NLTU Ukrainy, vol. 20.9, pp. 227-230. (in Ukrainian)

7. Levytska A.O. (2013) Metody otsinky konkurentospromozhnosti pidpryiemstva: vitchyzniani ta zakordonni pidkhody do klasyfikatsii [Methods of assessing the competitiveness of the enterprise: domestic and foreign approaches to classification]. Mekhanizm rehuliuvannia ekonomiky, no. 4, pp. 155-163. (in Ukrainian)

8. Yatsura, V.V., Zamroz M.V. (2011) Analiz metodiv otsinky konkurentospromozhnosti pidpryiemstv [Analysis of methods for assessing the competitiveness of enterprises]. Visnyk Volynskoho instytutu ekonomiky ta menedzhmentu. Zbirnyk naukovykh prats, no. 2. Available at: http://archive.nbuv.gov.ua/portal/Soc_Gum/Vviem/2011_2/18.pdf (in Ukrainian)

9. TOV «Khotel Menedzhment Hrup» [Hotel Management Group Company]. Available at: https://hotel-management-group.business-guide.com.ua/ (accessed 07 December 2021). 